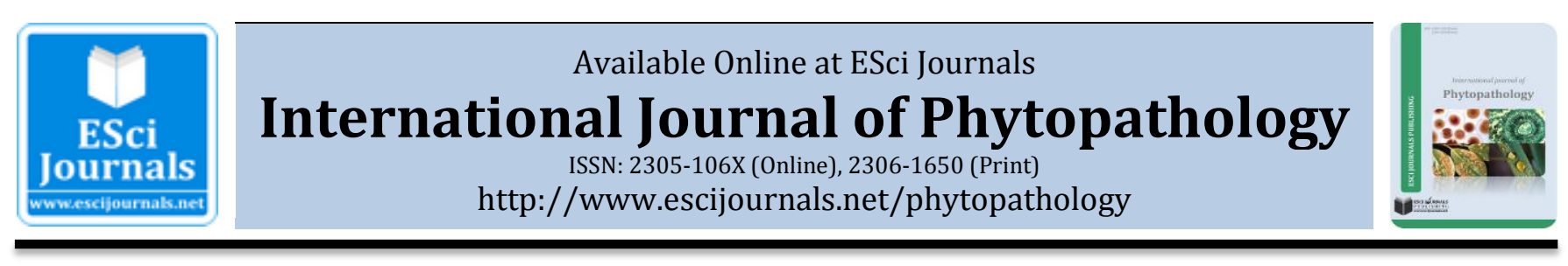

\title{
STUDIES ON FUNGI ISOLATED FROM DIOSCOREA ROTUNDATA (YAM) COLLECTED FROM OPEN MARKETS IN LAGOS NIGERIA
}

\author{
${ }^{a} A d e o g u n$ O. Oluwagbenga*, aAdekunle A. Adedotun, aSamuel O. Temitope, bbabhi A. Margaret \\ a Department of Botany, University of Lagos, Akoka, Lagos State, Nigeria. \\ b Distance Learning Institute, University of Lagos, Akoka, Lagos, Nigeria.
}

\section{A B S T R A C T}

Healthy and diseased white yams tubers (Dioscorea rotundata) were collected from three different open markets in Lagos State. Fungi were isolated from the yam twice monthly for three months. The fungi isolated were identified as Aspergillus niger, Aspergillus flavus, Mucor racemosa, Botryodiplodia thoebromae and Macrophomina phaseolina. A. niger and A. flavus were found to be the most prevalent fungi isolates while the occurrence of B. thoebromae, M. phaseolina and Mucor racemosa were less prevalent. Selected fungicides (Captan, Dithane M45, Difolatan and Benlate) were assayed against the fungal isolates. Captan and Dithane showed the highest inhibitory activity against all the isolates. The proximate analysis revealed the real gradual reduction in ash, lipid and crude fibre contents in the diseased yam tubers with reference to healthy yam except protein and moisture that had an insignificant increase in the diseased yam. The results highlight the potential of the fungicides for post-harvest preservation of Dioscorea rotundata in which the viability has been reduced because of post-harvest losses.

Keywords: Discorea rotundata, Fungi, Fungicides, Postharvest deterioration, Proximate composition.

\section{INTRODUCTION}

The disparity between the rate of population growth and the low yield of food produced for consumption is quite startling and the consequential effect of these on developing nations seem to be ominous. The reduction in the yield of food crops such as cassava, yam, maize and rice which are common staple food in Africa is on the increase (Ewku, 2005; Osunde, 2008). Yam which is one of the most consumed staple food in West Africa belongs to the genus Dioscorea (Family Dioscoreaceae) and is the second most important tropical root crop in West Africa after cassava (Osunde, 2008). The cultivation and harvesting of yams in West and Central Africa account for about $94 \%$ of world production and Nigeria is the leading producer (Akinwande et al., 2008). Yam with its appreciable content of essential dietary nutrients has been reported to have nutritional superiority when compared with other tropical root crops (Shajeela et al., 2011). Adeola et al. (2012)

\footnotetext{
* Corresponding Author:

Email: adeogunoluwagbenga@gmail.com

(C) 2014 ESci Journals Publishing. All rights reserved.
}

highlighted the important yam species in Nigeria to include Dioscorea rotundata (white yam), Dioscorea alata (white yam), Dioscorea cayensis (yellow yam), Dioscorea bulbifera (aerial yam or air potato), Dioscorea esculenta (Chinese yam) and Dioscorea dumentorium (trifoliate yam).

$D$. rotundata popularly known as white yam is the most widely cultivated and consumed of the Dioscorea spp. in Nigeria (Ezenibekwe et al., 2009). The tuber is about $1.6 \mathrm{~m}$ in height and weighs about $2-5 \mathrm{~kg}$ depending on size. The tuber has a rough skin usually dark to light brown in colour (Alinor and Akalezi, 2010). Nutritionally, yams are mainly carbohydrate food, but contain about $1-2 \%$ dietary protein, which is high compared with other tropical root crops (Ogaraku and Usman, 2008).Yams are therefore, able to provide a good proportion of protein requirement of man when consumed in large quantities (Ajayi, 2012). In Nigeria, yams are processed into staple, intermediate end product which are used for direct consumption by animals, used as basic ingredients for snacks or made into flour (Ezenibekwe et al., 2009). 
However, disease causing agents reduce the quantity and quality of yam produced by making them unappealing to the consumer. Yam is prone to infection right from the seedling stage through harvesting and in storage (Amusa et al., 2003). Different genera of fungi have been found to be associated with deterioration of yam tubers in storage and about thirty different fungi are involved in yam rot after harvest (Ikotun, 1989 and Ezenibekwe et al., 2009).

The aim of this research work is to examine the fungi associated with diseased yam in open markets in Lagos state, ascertain nutritional composition variability of the healthy and diseased yam and explore the fungicidal ability of some fungicides against the causal organisms of infection.

\section{MATERIALS AND METHODS}

Isolation of Fungi from the Samples of Dioscorea rotundata: Yam tubers used for this investigation were collected from the local markets of Bariga, Mushin and Oyingbo, in Lagos, Nigeria. Both healthy and diseased tubers were collected after which the diseased parts of the yam were separated from the healthy ones on the basis of the presence or absence of visible symptoms. The yams were sampled from the market twice a month for three months.

The method of Adekunle and Oluyode (2005) and Ezeibekwe (2009) were employed in isolating fungi from the diseased samples. Diseased tubers (from each of the market) that had been cut into discs $(5 \mathrm{~mm})$ were surface sterilized by leaving for 60 secs in $40 \%$ Sodium Hypochloride $(\mathrm{NaOCl})$ solution. These were rinsed in distilled water and later placed (using sterile forceps) into already prepared sterile solidified PDA in Petridishes, thereafter incubated at room temperature (28$31^{\circ} \mathrm{C}$ ) in the incubator and observed daily to ascertain the growth of fungi. To obtain a pure culture, resultant fungal isolates were repeatedly sub-cultured into sterile PDA plates until pure fungal isolates were obtained.

Identification of Fungi from Diseased Yam: The identity of the fungi were observed via morphological examination which include the size, shape, colour, spore formation and the number of days taken for the fungus to reach maximum diameter $(9 \mathrm{~cm})$ of the Petri dish (Adekunle and Oluyode, 2005). The texture of fungal growth was also observed. After 2 - 4 days of growth, the spore-bearing mycelia were then carefully sectioned, teased out and stained on a slide to observe with a light microscope. The fungi identified were confirmed by comparing their morphology and cultural characteristics with descriptions given by Domoschet $e t$ al. (1980) and Bryce (1992). The photomicrographs of the fungi were obtained via the Motic Camera 2000, 2.0 Megapixel.

Preparation of Innoculum for Fungicidal Activity: The fungi for the fungicidal assays were obtained via pure culture plates of organisms. The spore suspensions of the fungi were made using sterilized normal saline water of $10 \mathrm{ml}$. Drops of the spore suspensions were placed on a sterile glass slide using a sterile dropper. The suspensions were observed under the microscope to ascertain the presence of the fungal spore, conformity with the 0.5 MacFarland solution and the spores were later counted using hemocytometre (Adekunle and Ikumapayi, 2006).

Fungicides for Fungicidal Activity: Captan (Manufacturer: Famoz), Dithane M45 (Manufacturer: Dow AgroSciences), Benlate (Manufacturer: Du Pont) and Difolatan (Manufacturer: Florida Spectrum).

Preparation of Disc for Fungicidal Assay: The discs for fungicidal activity were prepared as described by Adekunle and Ikumapayi (2006). The discs (Filter papers Whatman No. 1) were sterilized in an autoclave at $126^{\circ} \mathrm{C}$ for $15 \mathrm{~min}$ and dried in an oven at $60^{\circ} \mathrm{C}$ for $30 \mathrm{~min}$. The discs were later soaked in the solution prepared with fungicides for $24 \mathrm{hr}$ prior to use.

Determination of Fungicidal Assay of Fungicides against Isolated Fungi: The disc diffusion method by Adekunle and Ikumapayi (2006) was adopted for the fungicidal assay. The tests were conducted with authenticated pure cultures of the fungi to determine their respective tolerance of the fungicides. A preparation of $0.5 \mathrm{ml}$ of the stocked suspension of each fungus was dropped aseptically using a dropper over the entire agar surface of a freshly prepared Potato dextrose agar (PDA) plates and evenly spread using a spreader. This was done to ensure an even distribution of the spores and later dried at room temperature for $15 \mathrm{~min}$ prior to the application of the discs on the agar plates. The discs (4) which have been soaked in solution prepared with fungicides were placed at the four edges on the surface of the agar plate with the aid of a sterilized forceps. The inoculated plates were later placed in an incubator at $28^{\circ} \mathrm{C}$. The plates were observed for zones of inhibition after 48hrs. The extent of inhibition was determined by measuring the diameter of the inhibition zone using a transparent half $(1 / 2)$ metre 
rule (Booths et al., 1971). The mean zones of inhibition of the three replicates were expressed in millimetres. The discs were also soaked in equivalent volume of sterilized distilled water and used as control.

Proximate Analysis of Healthy and Diseased Yam Estimation of Carbohydrate Content: The method of Egan et al. (1981) as modified by Adekunle (1997) was used to determine the carbohydrate content in the samples. Five grammes of the sample were added to 100 $\mathrm{ml}$ of distilled water and $50 \mathrm{ml}$ of $80 \%$ methanol to extract soluble carbohydrate. This was shaken for $1 \mathrm{hr}$ on an electric shaker, filtered through ashless filter paper (Whatman, London) and washed with $25 \mathrm{ml}$ distilled water. The aliquot was stored, while the insoluble residue was refluxed for $15 \mathrm{~min}$ with $200 \mathrm{ml}$ Hydrochloric acid/water mixture $(1: 10 \mathrm{v} / \mathrm{v})$. It was then cooled and neutralised with Sodium hydroxide $(\mathrm{NaOH})$ to a $\mathrm{pH}$ of 7.0. The solution was mixed with the aliquot stored. Thereafter, the following were added: $65 \mathrm{ml}$ of $0.3 \mathrm{M}$ Barium hydroxide $\left(\mathrm{Ba}(\mathrm{OH})_{2}\right)$ and $65 \mathrm{ml}$ of $5 \%$ $\mathrm{ZnSO}_{4} .7 \mathrm{H}_{2} \mathrm{O}$. The resulting solution was centrifuged at centrifugal acceleration ' $G$ ' of 0.444 metres per minute squared (1500rpm) for $15 \mathrm{~min}$ to precipitate the proteins. The filtrate was poured into $250 \mathrm{ml}$ flask and distilled water was added to make up $100 \mathrm{ml}$. One $\mathrm{ml}$ of this solution was poured into a test-tube and $4 \mathrm{ml}$ of anthrone reagent prepared by adding $0.2 \mathrm{~g}$ of anthrone to $100 \mathrm{ml}$ concentrated sulphuric acid. A blank prepared with distilled water instead of the sample was added to the anthrone solution. The solution in the test-tubes were shaken well and boiled in a water-bath $\left(100^{\circ} \mathrm{C}\right)$ for $10 \mathrm{~min}$. The optical density was then read at $620 \mathrm{~nm}$ using spectrophotometer (model 12471, Tokyo).

Estimation of Protein Content: The protein content of the samples was determined using Lowry et al. (1951) as modified by Adekunle (1997). Four grammes of the sample was suspended into $40 \mathrm{ml}$ of distilled water and shaken manually for $30 \mathrm{~min}$ before filtering through a filter paper (Whatmann, London), which was rinsed twice. Ammonium sulphate $\left[\left(\mathrm{NH}_{4}\right)_{2} \mathrm{SO}_{4}\right]$ was added to the filtrate until saturated. The resulting solution was then centrifuged at an acceleration of 0.555 metres per minute squared (2500rpm) for $20 \mathrm{~min}$. The residue was dissolved in $10 \mathrm{ml}$ of $0.3 \mathrm{M} \mathrm{NaOH}$ of which $0.2 \mathrm{ml}$ was added to 0.8 $\mathrm{ml}$ of distilled water giving $1 \mathrm{ml}$ of sample extract.

Solution A was prepared by dissolving $2 \mathrm{~g}$ of Sodium carbonate $\left(\mathrm{Na}_{2} \mathrm{Co}_{3}\right), 40 \mathrm{~g}$ of $\mathrm{NaOH}$ and $0.2 \mathrm{~g}$ of Sodium potassium tartrate in one 1ltr of distilled water. Solution
B was prepared by dissolving 0.5g of Copper (II) sulphate in $100 \mathrm{ml}$ of distilled water. Solution A and B were kept in the refrigerator and mixed in ratio 50:1 (A:B) before used to obtain solution C. Five millilitres of solution $\mathrm{C}$ was added to $1 \mathrm{ml}$ of sample extract and left for $10 \mathrm{~min}$. Thereafter, $1 \mathrm{ml}$ of folin ciocalteu phenol reagent in distilled water prepared at a ration 1:1, was added to the solution and left for 30min. A blank was prepared by adding $1 \mathrm{ml}$ of folin ciocalteu phenol reagent solution. The solutions were then read on the spectrophotometer at a wavelength of $660 \mathrm{~nm}$.

Determination of Moisture Content: This method was adopted from Chinedu and Nwinyi (2012), which is based on moisture evaporation. The crucibles were washed dried in oven and in desiccators for cooling. The weight of each crucible was taken. Twenty grammes of the sample were weighed into a sterile crucible; weight of the dish and weight of un-dried sample were taken. This was transferred into an oven set at $80^{\circ} \mathrm{C}$ for $2 \mathrm{hr}$ and at $100^{\circ} \mathrm{C}$ for $3 \mathrm{hr}$ respectively. This was removed and cooled in desiccators. Then the weight was measured using a measuring analytical balance. It was transferred back into the oven for another one hour and then reweighed. The process continued until a constant weight was obtained. The difference in weight between the initial weight and the constant weight represents the moisture content.

Calculation: The loss in weight multiplied by 100 over the original weight is percentage moisture content.

$$
\begin{aligned}
& \text { Moisture content }\left(\frac{\mathrm{g}}{100} \mathrm{~g}\right) \\
& =\frac{\text { Loss in weight }(\mathrm{W} 2-\mathrm{W} 3)(\mathrm{g})}{\text { Original weight of sample } \mathrm{g}(\mathrm{W} 2-\mathrm{W} 1)} \times 100
\end{aligned}
$$

Where $W_{1}=$ initial weight of empty crucible, $W_{2}=$ weight of crucible + food before drying, $W_{3}=$ final weight of crucible + food after drying.

$\%$ Total solid (dry matter) $(\%)=100-$ moisture (\%)

Determination of Ash Content: The ash represents the inorganic component (minerals) of the sample after all moisture has been removed as well as the organic material. The method adopted from Chinedu and Nwinyi (2012) is a destructive approach based on the decomposition of all organic matter such that the mineral elements may be lost in the process. Five grammes of the samples were weighed into a clean dried and cooled crucible. It was put into a furnace set at 550 to $600^{\circ} \mathrm{C}$ and allowed to blast for $3 \mathrm{hr}$. It was then brought out and allowed to cool in a desiccator and weighed again. 
Calculation: Percentage weight is calculated as weight of ash multiplied by 100 over original weight of the samples used.

$$
\begin{aligned}
\text { Ash content } & =\frac{\text { Weight of ash }(\mathrm{g})}{\text { Weight of original sample used }} \times 100 \\
& \frac{\text { Loss in weight }(\mathrm{W} 3-\mathrm{W} 1)(\mathrm{g})}{\mathrm{W} 2-\mathrm{W} 1} \times 100
\end{aligned}
$$

Where $\mathrm{W}_{1}=$ weight of empty crucible, $\mathrm{W}_{2}=$ weight of crucible + food before drying and or ashing, $\mathrm{W}_{3}=$ weight of crucible + ash.

Determination of Crude Fibre Content: The bulk of roughages in food is referred to as fibre and is estimated as crude fibre based on method applied by Chinedu and Nwinyi (2012). Twenty grammes of the samples were defatted with diethyl ether for $8 \mathrm{hr}$ and boiled under reflux for exactly 30 min with $200 \mathrm{ml}$ of $1.25 \% \mathrm{H}_{2} \mathrm{SO} 4$. It was then filtered through cheese cloth on a flutter funnel. This was later washed with boiling water to completely remove the acid. The residue was then boiled in a round bottomed flask with $200 \mathrm{ml}$ of $1.25 \% \mathrm{NaOH}$ for another $30 \mathrm{~min}$ and filtered through previously weighed crucible. The crucible was then dried with samples in an oven at $100^{\circ} \mathrm{C}$, left to cool in desiccators and later weighed. This was later incinerated in a muffle furnace at $600^{\circ} \mathrm{C}$ for $2-3 \mathrm{hr}$ and later allowed to cool in desiccators and weighed.

Calculation $=$ Weight of fibre $=\left(\mathrm{C}_{2}-\mathrm{C}_{3}\right) \mathrm{y}$

$$
\% \text { Fibre } \frac{\mathrm{C} 2-\mathrm{C} 3}{\text { Weight of Original Sample }} \times 100
$$

Determination of Fat Content: The method employed was the soxhlet extraction technique described by Chinedu and Nwinyi (2012). Four grammes of the samples were weighed and carefully placed inside a fat free thimble. This was covered with cotton wool to avoid the loss of sample. Loaded thimble was put in the soxhlet extractor, $60 \mathrm{ml}$ of petroleum ether were poured into a weighed fat free soxhlet flask and the flask was attached to the extractor. The flask was placed on a heating mantle so the petroleum ether in the flask refluxed. Cooling was achieved by a running tap connected to the extractor for at least $6 \mathrm{hr}$ after which the solvent was completely siphoned into the flask. Rotary vacuum evaporator was used to evaporate the solvent leaving behind the extracted lipids in the soxhlet. The flask was removed from the evaporator and dried to a constant weight in the oven at $60^{\circ} \mathrm{C}$. The flask was then cooled in a desiccator and weighed. Each determination was done in triplicate. The amount of fat extracted was calculated by difference.

Ether extracts $(100 \mathrm{~g})$ dry matter

\section{RESULTS}

$$
=\frac{\text { weight of extracted lipids }(\mathrm{g})}{\text { weight of dry sample }(\mathrm{g})} \times 100
$$

This study shows the presence of Aspergillus niger, Aspergillus flavus, Mucor racemosa, Botryodiplodia thoebromae and Macrophomina phaseolina isolated from the diseased tubers of yam from three local markets (Bariga, Mushin and Oyingbo) in Lagos for a period of 3 months as elucidated on figure 1 . The survey indicates the prevalence of Aspergillus flavus and Aspergillus niger in all samples collected from the markets. This study also revealed as posit in table 1 that the fungicidal activity of the fungicides against the fungi with captan had the highest zone of inhibition of $20.0 \mathrm{~mm} \pm 0.0$ against $A$. niger while benlate had lowest zone of inhibition of $5.0 \mathrm{~mm} \pm 0.0$; Dithane M 45 with $30.5 \mathrm{~mm} \pm 0.5 \mathrm{~mm}$ showed highest zone of inhibition against $M$. racemosa and $28.3 \mathrm{~mm} \pm 1.2$ had the highest zones of inhibition against B. theobromae and Difolatan with $5.0 \mathrm{~mm} \pm 0.0$ and $5.0 \mathrm{~mm} \pm 0.0$ against Aspergillus flavus and Mucor racemosa respectively; these were widely differentiated based on significance differences $(\mathrm{P} \leq 0.05)$.

A comparative activity of the fungicides with fungal isolates as fixed factors as surmised on table 2 revealed statistically that there is significant difference $(\mathrm{P} \leq$ 0.05 ) among the fungicides with reference to fungal isolates except for Aspergillus niger (Captan and Dithane M45, Difolatan and Benlate, Difolatan and control, Benlate and control), Aspergillus flavus (Captan and Dithane, Benlate and Difolatan, Benlate and control), Mucor racemosa (Difolatan and control), Botryplodia theobromae (Benlate and control) and Macrophomina phaseolina (Difolotan and Benlate, Difolatan and control, Benlate and control)in which there were no significance difference. Plates 1-5 depict the photomicrographs of the fungi isolates. The nutritional composition of the yam as exemplified in table 3 shows the mean values of the yam when it was healthy and infected; carbohydrate content of healthy yam is $45.6 \% \pm 0.1$, diseased yam is $42.8 \% \pm 0.32$, protein content of healthy yam is $45.6 \% \pm 0.1 \%$ while the protein content of diseased yam is $42.8 \% \pm 0.32$, fat content of healthy yam is $0.37 \% \pm 0.01$ and diseased yam is $0.24 \% \pm 0.01$, moisture content of healthy yam is $42.7 \% \pm 0.1$. 


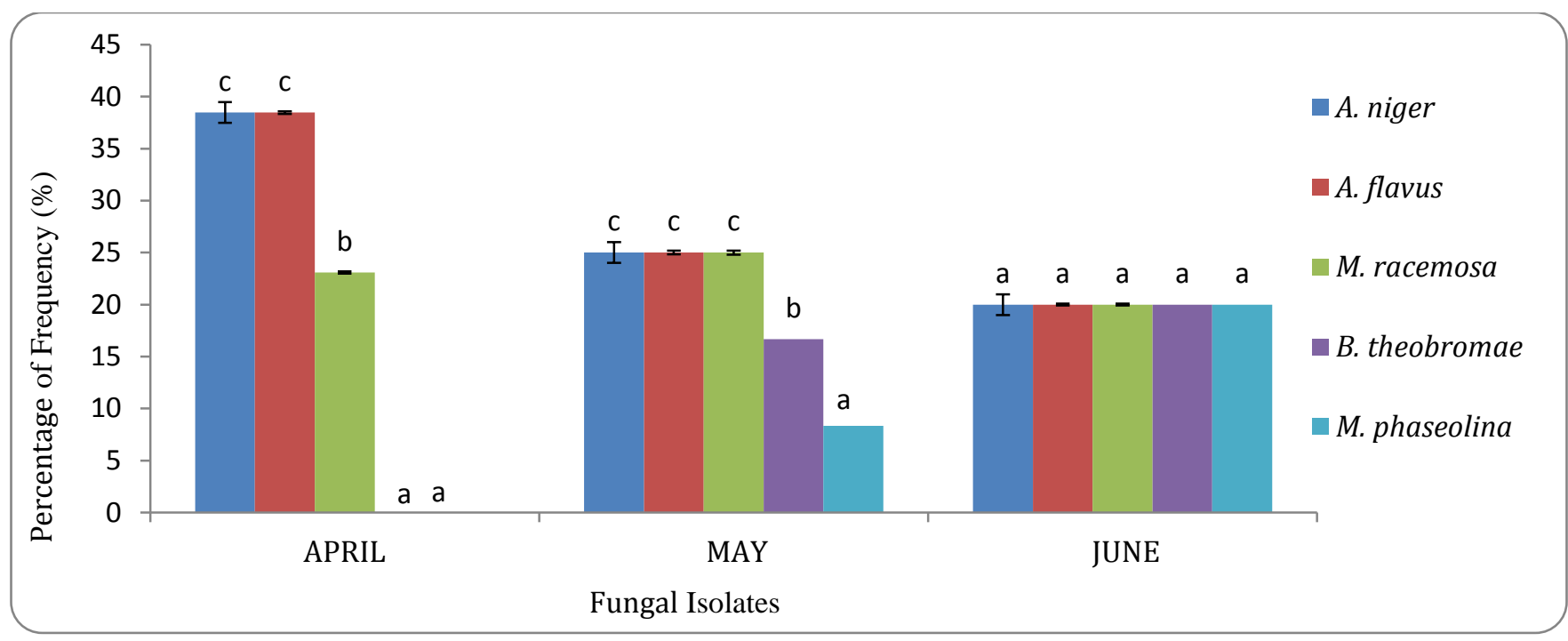

Figure 1. Percentage frequency of spoilage fungi in the three open markets in Lagos.

Table 1. Fungicidal activity of some fungicides against the isolated fungi.

\begin{tabular}{lccccc}
\hline FUNGI & CAPTAN $(\mathrm{mm})$ & DITHANE M45 $(\mathrm{mm})$ & DIFOLATAN $(\mathrm{mm})$ & BENLATE $(\mathrm{mm})$ & CONTROL $(\mathrm{mm})$ \\
\hline A. Niger & $20.0 \pm 0^{\mathrm{b}}$ & $16.3 \pm 3.8^{\mathrm{b}}$ & $7.3 \pm 0.5^{\mathrm{a}}$ & $5.0 \pm 0^{\mathrm{a}}$ & $5.0 \pm 0^{\mathrm{a}}$ \\
A. flavus & $15.0 \pm 2.0^{\mathrm{c}}$ & $16.5 \pm 1.2^{\mathrm{c}}$ & $5.0 \pm 0.0^{\mathrm{a}}$ & $7.3 \pm 0.3^{\mathrm{ab}}$ & $5.0 \pm 0^{\mathrm{a}}$ \\
M. racemosa & $23.8 \pm 1.3^{\mathrm{c}}$ & $30.5 \pm 0.5^{\mathrm{d}}$ & $5.0 \pm 0^{\mathrm{a}}$ & $12.5 \pm 1.4^{\mathrm{b}}$ & $5.0 \pm 0^{\mathrm{a}}$ \\
B. theobromae & $20.0 \pm 0^{\mathrm{c}}$ & $28.3 \pm 1.2^{\mathrm{d}}$ & $5.0 \pm 0^{\mathrm{b}}$ & $5.0 \pm 0^{\mathrm{a}}$ & $5.0 \pm 0^{\mathrm{a}}$ \\
M. phaseolina & $19.8 \pm 1.7^{\mathrm{c}}$ & $10.0 \pm 0^{\mathrm{b}}$ & $5.0 \pm 0^{\mathrm{a}}$ & $5.0 \pm 0^{\mathrm{a}}$ & $5.0 \pm 0^{\mathrm{a}}$ \\
\hline
\end{tabular}

Values are expressed as Mean \pm SE. mean with the same letter within a column are not significantly different at $\mathrm{P}<0.05$.

Table 2. A Comparison of the fungicidal activity of the fungicides with the fungal isolates as fixed factors.

\begin{tabular}{|c|c|c|c|c|}
\hline Fungal Isolates & Fungicide (I) & Fungicide (J) & Mean Difference (I-J) & $P$ value \\
\hline \multirow[t]{20}{*}{ Aspergillus niger } & Captan & Dithane M45 & 3.750000 & 0.138 \\
\hline & & Difolatan & $12.750000^{*}$ & 0.000 \\
\hline & & Benlate & $15.000000^{*}$ & 0.000 \\
\hline & & Control & $15.000000^{*}$ & 0.000 \\
\hline & Dithane M45 & Captan & -3.750000 & 0.138 \\
\hline & & Difolatan & $9.000000^{*}$ & 0.002 \\
\hline & & Benlate & $11.250000^{*}$ & 0.000 \\
\hline & & Control & $11.250000^{*}$ & 0.000 \\
\hline & Difolatan & Captan & $-12.750000^{*}$ & 0.000 \\
\hline & & Dithane M45 & $-9.000000^{*}$ & 0.002 \\
\hline & & Benlate & 2.250000 & 0.362 \\
\hline & & Control & 2.250000 & 0.362 \\
\hline & Benlate & Captan & $-15.000000^{*}$ & 0.000 \\
\hline & & Dithane M45 & $-11.250000^{*}$ & 0.000 \\
\hline & & Difolatan & -2.250000 & 0.362 \\
\hline & & Control & .000000 & 1.000 \\
\hline & Control & Captan & $-15.000000^{*}$ & 0.000 \\
\hline & & Dithane M45 & $-11.250000^{*}$ & 0.000 \\
\hline & & Difolatan & -2.250000 & 0.362 \\
\hline & & Benlate & .000000 & 1.000 \\
\hline \multirow[t]{4}{*}{ Aspergillus flavus } & Captan & Dithane M45 & -1.500000 & 0.334 \\
\hline & & Difolatan & $5.250000^{*}$ & 0.003 \\
\hline & & Benlate & $8.000000^{*}$ & 0.000 \\
\hline & & Control & $10.000000^{*}$ & 0.000 \\
\hline
\end{tabular}




\begin{tabular}{|c|c|c|c|c|}
\hline & \multirow[t]{4}{*}{ Dithane M45 } & Captan & 1.500000 & 0.334 \\
\hline & & Difolatan & $6.750000^{*}$ & 0.000 \\
\hline & & Benlate & $9.500000^{*}$ & 0.000 \\
\hline & & Control & $11.500000^{*}$ & 0.000 \\
\hline & \multirow[t]{4}{*}{ Difolatan } & Captan & $-5.250000^{*}$ & 0.003 \\
\hline & & Dithane M45 & $-6.750000^{*}$ & 0.000 \\
\hline & & Benlate & 2.750000 & 0.087 \\
\hline & & Control & $4.750000^{*}$ & 0.006 \\
\hline & \multirow[t]{4}{*}{ Benlate } & Captan & $-8.000000^{*}$ & 0.000 \\
\hline & & Dithane M45 & $-9.500000^{*}$ & 0.000 \\
\hline & & Difolatan & -2.750000 & 0.087 \\
\hline & & Control & 2.000000 & 0.203 \\
\hline & \multirow[t]{4}{*}{ Control } & Captan & $-10.000000^{*}$ & 0.000 \\
\hline & & Dithane M45 & $-11.500000^{*}$ & 0.000 \\
\hline & & Difolatan & $-4.750000^{*}$ & 0.006 \\
\hline & & Benlate & -2.000000 & 0.203 \\
\hline \multirow{20}{*}{ Mucor racemosa } & \multirow[t]{4}{*}{ Captan } & Dithane M45 & $-5.250000^{*}$ & 0.034 \\
\hline & & Difolatan & $18.750000^{*}$ & 0.000 \\
\hline & & Benlate & $11.250000^{*}$ & 0.000 \\
\hline & & Control & $18.750000^{*}$ & 0.000 \\
\hline & \multirow[t]{4}{*}{ Dithane M45 } & Captan & $5.250000^{*}$ & 0.034 \\
\hline & & Difolatan & $24.000000^{*}$ & 0.000 \\
\hline & & Benlate & $16.500000^{*}$ & 0.000 \\
\hline & & Control & $24.000000^{*}$ & 0.000 \\
\hline & \multirow[t]{4}{*}{ Difolatan } & Captan & $-18.750000^{*}$ & 0.000 \\
\hline & & Dithane M45 & $-24.000000^{*}$ & 0.000 \\
\hline & & Benlate & $-7.500000^{*}$ & 0.005 \\
\hline & & Control & 0.000000 & 1.000 \\
\hline & \multirow[t]{4}{*}{ Benlate } & Captan & $-11.250000^{*}$ & .000 \\
\hline & & Dithane M45 & $-16.500000^{*}$ & .000 \\
\hline & & Difolatan & $7.500000^{*}$ & .005 \\
\hline & & Control & $7.500000^{*}$ & .005 \\
\hline & \multirow[t]{4}{*}{ Control } & Captan & $-18.750000^{*}$ & 0.000 \\
\hline & & Dithane M45 & $-24.000000^{*}$ & 0.000 \\
\hline & & Difolatan & .000000 & 1.000 \\
\hline & & Benlate & $-7.500000^{*}$ & 0.005 \\
\hline \multirow{16}{*}{$\begin{array}{l}\text { Botryodiplodia } \\
\text { theobromae }\end{array}$} & \multirow[t]{4}{*}{ Captan } & Dithane M45 & $-8.250000^{*}$ & 0.000 \\
\hline & & Difolatan & $6.750000^{*}$ & 0.001 \\
\hline & & Benlate & $15.000000^{*}$ & 0.000 \\
\hline & & Control & $15.000000^{*}$ & 0.000 \\
\hline & \multirow[t]{4}{*}{ Dithane M45 } & Captan & $8.250000^{*}$ & 0.000 \\
\hline & & Difolatan & $15.000000^{*}$ & 0.000 \\
\hline & & Benlate & $23.250000^{*}$ & 0.000 \\
\hline & & Control & $23.250000^{*}$ & 0.000 \\
\hline & \multirow{4}{*}{ Difolatan } & Captan & $-6.750000^{*}$ & 0.001 \\
\hline & & Dithane M45 & $-15.000000^{*}$ & 0.000 \\
\hline & & Benlate & $8.250000^{*}$ & 0.000 \\
\hline & & Control & $8.250000^{*}$ & 0.000 \\
\hline & \multirow[t]{4}{*}{ Benlate } & Captan & $-15.000000^{*}$ & 0.000 \\
\hline & & Dithane M45 & $-23.250000^{*}$ & 0.000 \\
\hline & & Difolatan & $-8.250000^{*}$ & 0.000 \\
\hline & & Control & .000000 & 1.000 \\
\hline
\end{tabular}




\begin{tabular}{|c|c|c|c|c|}
\hline \multirow{21}{*}{$\begin{array}{l}\text { Macrophomina } \\
\text { phaseoilina }\end{array}$} & Control & $\begin{array}{l}\text { Captan } \\
\text { Dithane M45 } \\
\text { Difolatan } \\
\text { Benlate } \\
\end{array}$ & $\begin{array}{l}-15.000000^{*} \\
-23.250000^{*} \\
-8.250000^{*} \\
.000000\end{array}$ & $\begin{array}{l}0.000 \\
0.000 \\
0.000 \\
1.000 \\
\end{array}$ \\
\hline & \multirow[t]{4}{*}{ Captan } & Dithane M45 & $9.750000^{*}$ & 0.000 \\
\hline & & Difolatan & $14.750000^{*}$ & 0.000 \\
\hline & & Benlate & $14.750000^{*}$ & 0.000 \\
\hline & & Control & $14.750000^{*}$ & 0.000 \\
\hline & \multirow[t]{4}{*}{ Dithane M45 } & Captan & $-9.750000^{*}$ & 0.000 \\
\hline & & Difolatan & $5.000000^{*}$ & 0.000 \\
\hline & & Benlate & $5.000000^{*}$ & 0.000 \\
\hline & & Control & $5.000000^{*}$ & 0.000 \\
\hline & \multirow[t]{4}{*}{ Difolatan } & Captan & $-14.750000^{*}$ & 0.000 \\
\hline & & Dithane M45 & $-5.000000^{*}$ & 0.000 \\
\hline & & Benlate & .000000 & 1.000 \\
\hline & & Control & .000000 & 1.000 \\
\hline & \multirow[t]{4}{*}{ Benlate } & Captan & $-14.750000^{*}$ & 0.000 \\
\hline & & Dithane M45 & $-5.000000^{*}$ & 0.000 \\
\hline & & Difolatan & .000000 & 1.000 \\
\hline & & Control & .000000 & 1.000 \\
\hline & \multirow[t]{4}{*}{ Control } & Captan & $-14.750000^{*}$ & 0.000 \\
\hline & & Dithane M45 & $-5.000000^{*}$ & 0.000 \\
\hline & & Difolatan & .000000 & 1.000 \\
\hline & & Benlate & .000000 & 1.000 \\
\hline
\end{tabular}

*The mean difference is significant at 0.05 level.

Table 3. Proximate composition of Healthy Yam and Diseased Yam.

\begin{tabular}{lcccccl}
\hline Nutrient & Healthy Yam (\%) & Diseased Yam (\%) & Mean Difference & p-value & t-value & d.f. \\
\hline Carbohydrate & $45.6 \pm 0.1$ & $42.80 \pm 0.32$ & 2.8 & 0.033 & 3.193 & 4 \\
Protein & $7.3 \pm 0.02$ & $9.2 \pm 0.04$ & -1.9 & 0.005 & -5.644 & 4 \\
Fat & $0.37 \pm 0.01$ & $0.24 \pm 0.01$ & 0.13 & 0.149 & 1.782 & 4 \\
Moisture & $42.7 \pm 0.1$ & $44.4 \pm 0.2$ & -1.7 & 0.001 & -8.878 & 4 \\
Ash & $1.54 \pm 0.01$ & $1.2 \pm 0.02$ & 0.36 & 0.006 & 5.270 & 4 \\
Fibre & $2.6 \pm 0.02$ & $1.8 \pm 0.1$ & 0.93 & 0.001 & 8.750 & 4 \\
\hline
\end{tabular}

Values are expressed as Mean \pm SE.

The diseased yam is $44.4 \% \pm 0.2$, ash content of healthy yam is $1.54 \% \pm 0.01$ and the diseased yam is $1.2 \% \pm 0.02$ and fibre of healthy yam is $1.54 \pm 0.01 \%$ while the diseased yam is $1.2 \pm 0.02 \%$. The significance difference $(\mathrm{P} \leq 0.05)$ between the healthy and diseased in the nutritional composition of the yam was expressive in carbohydrate, moisture and fibre contents of the yam while there was no significance difference in protein, ash and fat contents in the nutritional status of healthy and infected yam.

\section{DISCUSSION}

The fungi involved with yam tubers infections in the open markets was deduced through this study. It was inferred from the study that $A$. niger and A. flavus were prevalent which agrees with earlier work by Okigbo and Ogbonnaya (2006). Since these fungi were not latent infection pathogens, their constant isolation from postharvest yam tubers could be due to their prevalence in tropical areas such as Bariga, Mushin and Oyingbo. Okusanya and Yusuf (2008) reported a similar event in their study of fungi isolated from rotten yam tubers in Adamawa State. This study surmised the presence of Botryodiplodia theobromae and Macrophomina phaseolina from the diseased yam (Amusa et al., 2003).

The inhibitory activity of the fungicides on the test fungi showed that Captan had a wide-spectrum of activity. Captan is known to reduce fungal spore germination, growth and oxygen uptake (Richmond and Somers, 1963). The responsiveness of Dithane M45 in inhibiting fungal growth agrees with the earlier work of Nwachukwu (2006). Dithane M45 is known to possess protectant activity and the ability to disrupt respiratory 
activity of target fungi. The moderate activity of Benlate and difolatan corroborates earlier works by Daouda et al. (2010) and Taskeen-Un-Nisa et al. (2011).

The nutritional composition of the infected yam tubers deviates from the healthy yam as the carbohydrate content decreases in spoilt tubers compared to healthy yam which lay further credence to the work of Chuku (2012). The carbohydrate composition of the healthy yam $(45.6 \% \pm 0.1)$ deduced from this study slightly varied with that reported by Alimor and Akalezi (2010) which is $40.61 \% \pm 0.02$, this could have occurred due to post-harvest variation in composition. However, the protein content increased in diseased tubers $(9.2 \% \pm 0.04)$ compared to healthy tubers $(7.3 \% \pm 0.02)$, this also corroborate earlier report of Chuku (2012). This study shows that the nutritional content of yam is low of protein, this correspond earlier assertions by Alimor and Akalezi (2010) and Frank and Kingsley (2013). The fat content decreased in diseased yam $(0.24 \% \pm 0.01)$ compared to what was obtained from the healthy yam (0.37 \pm 0.01$)$. Contrarily, Sanyaolu et al. (2014) had earlier observed an increase in fat content in diseased Irvingia gabonensis. The moisture and ash content differences in the healthy yam and diseased yam agrees with Sanyaolu et al. (2014) which deduced that the decrease in moisture content might have occurred due to the presence of spoilage fungi while there was also a decrease in the fibre content of the diseased tubers. The decrease in the nutritive value when the yam is infected can be attributed to the influence of fungal contamination (Bankole et al., 2005). The spores of fungi are known to have caused some respiratory disease; apart from the deterioration in the nutritional worth of produce attributed to the influence of fungal attack (Sanyaolu et al., 2014), the production of mycotoxins, especially of some types, which are newly reported with some species of fungi in some places further highlights the human and animal health and safety concerns associated with the consumption of food materials that have suffered from fungal attack (Sanyaolu et al., 2014).

This study was able to look at the efficacies of some fungicides against some fungal isolates from diseased yam tubers. It was able to ascertain the reduction in nutritional composition of infected yam and this can be ascribed to the spoilage fungi isolated from the diseased yam.

\section{REFERENCES}

Adekunle, A. A. 1997. Fungal Post-Harvest Deterioration in Cucumeropsis Manii Naud-Holl Seeds. Ph.D Thesis, University of Lagos, Nigeria. 250pp.

Adekunle, A. A. and A. M. Ikumapayi. 2006. Antifungal Property and Phytochemical Screening of the Crude Extracts of Funtumia elastic and Mallotus oppositifolius. West Indian Medical Journal. 55(4): 219-223.

Adekunle, A. A. and T. F. Oluyode. 2005. Biodegradation of Crude Petroleum and Petroleum Products by Fungi isolated from two Oil Seeds (Melon and soybean seeds). Journal of Environmental Biology. 26(1): 37-42.

Adeola, A. A., B. O. Otegbayo and S. Ogunnoiki. 2012. Preliminary Studies on the Development and Evaluation of Instant Pounded Yam from Dioscorea alata. Journal of Applied Science and Environmental Management. 16 (3): 287 - 290.

Akinwande, B. A., O. A. Abiodun. I. A. Adeyemi and C. T. Akanbi. 2008. Effect of Steaming method and time on the Physical and Chemical Properties of Flour from Yam Tubers. Available online at: http://www.ajol.info/journals/nifoj (accessed on 4 June, 2014).

Ajayi, A. 0. 2011. Sustainable Dietary Supplements: An Analytical Study of African Yam Bean-Sphenostylis sternocarpa and Corn-Zea May. European Journal of Experimental Biology. 1(4): 189-201.

Alinnnor, I. J. and C. O. Akalezi. 2010. Proximate and Mineral Compositions of Discorea rotundata (White Yam) and Colocasia esculenta (White Cocoyam). Pakistan Journal of Nutrition. 9(10): 998-1001.

Amusa, N. A. A. A. Adegbite, S. Muhammed and R. A. Baiyewu. 2003. Yam Diseases and its management in Nigeria. African Journal of Biotechnology. 2(12): 497-502.

Bankole, S. A., A. Osho, A. O. Joda and O. A. Enikuomehin. 2005. Effect of Drying Method on the Quality of 'Egusi' Melon Seeds (Colocynthis citrullus L.). African Journal of Biotechnology, 4(8): 799-803.

Bryce, K. 1992. The fifth Kingdom. Mycologue Publications, Ontario. 412pp.

Chinedu, S. N. and C. O. Nwinyi. 2012. Proximate analysis of Sphenostylis stenocarpa and Voadzeia subterranean consumed in South-Eastern Nigeria. 
Journal of Agricultural Extension and Rural Development. 4(3): $57-62$.

Chuku, E. C. 2012. Effects of wrapping materials on Mould Growth and Proximate Composition of Pentaclethra macrophylla Benth. Nigerian Journal of Mycology. 4: 57-64.

Dauda, K., C. Brahima, B. Jean, D. Mohammed, S. Sibrina, N. Carine and B. Lezin. 2010. Fungicides and Biological Products Activities towards Fungi causing diseases on banana and vegetable in Cote d'Ivoire, Fungicides, Odile Carisse (Ed.), ISBN:978953-307-266, In Tech, Available from http://www.intechopen.com/books/fungicides/a ctivity-of-fungicides-and-biological-products-onfungi-causing-diseases-on-banana-and-vegetablein (accessed 4 June, 2014).

Deacon, J. W. 1980. Introduction to Modern Mycology. Blackwell Scientific Publications, London. 197pp.

Domoschet, K. H., B. Gams and T. Anderson. 1980. Compendium of soil fungi vol.1. Academic Press, London: 859pp.

Egan, H., H. S. Kirk and R. Sawyer. 1981. Pearson's Analysis of Foods. Churchill Livingstone Publishers. Edinburgh, Scotland. 596pp.

Ekwu, F. C., N. O. Ozo and O. J. Ikegwu. 2005. Quality of Fufu flour from white yam varieties (Discorea spp.) Nigerian Food Journal. 23: 107-113.

Ezeibekwe, I. O., M. I. Opara and F. N. Mbagwu. 2009. Antifungal Effect of Aloe-vera Gel on Fungal Organisms Associated with Yam (Discorea rotundata,Poir) Rot. Journal of Molecular Genetics. 1(1): 11-17.

Frank, C. O. and C. A. Kingsley. 2014. Proximate Composition, Physiological Changes during Storage, and Shelf Life of Some Nigerian varieties of Yams (Dioscorea species). Journal of Scientific Research and Reports. 3(4): 553-562.

Ikotun, T. 1989. Disease of Yam tubers. International journal of tropical plant disease. 7: 1-21.

Lowry, O. H., Rosebugh, N. J., Faw, A. L. and Randall, R. Z. (1951). Protein Measurements of Folin ciocalteu phenol reagent. Journal of Biological Chemistry, 193: 265-275.

Nwachukwu, E. 2006. Susceptibility of Yam (Dioscorea rotundata) to Biodeterioration following different
Chemical Treatment. Journal of sustainable Agriculture and the Environment. 8:39-43.

Ogaraku, A. O. and H. O. Usman. 2008. Storage Rot of Some Yams (Dioscorea spp) in Keffi and Environs, Nasarawa State, Nigeria. Production Agriculture and Technology journal. 4 (2): 22-27.

Okigbo, R. and F. Ikediugwu. 2000. Studies on Biological Control of Postharvest Rot of Yam (Dioscorea spp) with Trichoderma viride. Journal of Phytopathology. 148:351-355.

Okigbo, R. N. and U. O. Ogbonnaya. 2006. Antifungal Effects of Two Tropical Plant Leaf Extracts (Ocimum gratissimum and Aframomum melegueta) on Postharvest Yam (Discorea spp.) Rot. African Journal of Biotechnology. 5(9): 727-731.

Opara, L. 2003. Yams: Post Harvest Operation. Massey University Press, Palmerston North, New Zealand. Pp 7-12.

Osagie, A. 1992. The Yam Tubers in Storage Postharvest Unit, University of Benin, Nigeria. Pp 107-173.

Osunde, Z. D. 2008. Minimizing Postharvest Losses in Yam (Discorea spp.):Treatments and Techniques. In: Food Science and Technology to improve Nutrition and Promote National Development, Robertson, G.L. and Lupien, J.R. (Eds). International Union of Food Science and Taxonomy. Pp. 1-12.

Richmond, D. and E. Somers. 1963. Studies on the Fungitoxicity of Captan. Relation between the sulfhydryl content of Fungal spores and their uptake of Captan. Annal of Applied Biology. 52:327-336.

Sanyaolu, A. A., A. A. Adekunle and A. Osuntoki. 2014. The Effects of Post-harvest Mycodeterioration on the Proximate Composition of Irvingia gabonensis seeds, International Journal of Phytopathology. 3(1): 41-48.

Shajeela, P. S., V. R. MohanJesudas. L. L and P. T. Soris. 2011. Nutritional and antinutritional evaluation of wild yam (Dioscorea spp.). Tropical and Subtropical Agroecosystems. 14: 723-730.

Taskeen-Un-Nisa, A., A. Wani, M. Bhat, S. Pala and R. Mir. 2011. In vitro inhibitory effect of fungicides and botanicals on mycelial growth and spore germination of Fusarium oxysporum. Journal of Biopesticides. 4(1): 53-56. 